\title{
Dutch trade and patronage networks as facilitators of transcontinental mobility in early modern Russia and the VOC Cape
}

\author{
B. Gorelik and G.J. Schutte*
}

\begin{abstract}
The Swellengrebels were the most important family at the Cape under Dutch East India Company (VOC) rule to become members of the Netherlands governing elite. Hendrik Swellengrebel was the colony's only locally-born governor, while his father and other members of the family at the Cape were born in Russia. Their migration between Europe, Africa and Asia reflected the development and functioning of the Dutch trade and patrimonial networks. Even on the periphery, at the Cape and among Dutch expatriates in Russia, those networks provided opportunities for overseas employment and upward social mobility. The case of the Swellengrebels shows that not only goods but also people could make their way from Russia to the Cape and the VOC Asia. Patronage enabled both spatial and upward social mobility. Keeping mutually beneficial relations with influential patrons such as Nicolaes Witsen, members of the Swellengrebel family navigated their way within the Dutch trade networks and achieved prosperity and a high status in such culturally diverse societies as Russia and the Cape. The social advancement, identity transformations and transcontinental migrations of the Swellengrebel family demonstrate the materiality of transcontinental patrimonial networks in the early modern period.
\end{abstract}

Keywords: Hendrik and Johannes Swellengrebel; migration; Nicolaes Witsen; patrimonial networks; patronalism; patronage; Russia; social identity; upward social mobility; VOC Cape.

\section{Opsomming}

Die Swellengrebels was die vernaamste van die Kaapse families wat onder die bewind van die Verenigde Oost-Indische Compagnie (VOC) lid geword het van die Nederlandse regerende elite. Hendrik Swellengrebel was die kolonie se enigste plaaslik gebore

* $\quad$ Boris Gorelik is a senior research fellow, Centre for Southern African Studies, Institute for African Studies, Russian Academy of Sciences, Moscow, Russia. He specialises in the history of Russian-South African contacts and Russian perceptions of South Africa. His email address is boris.gorelik@inafr.ru. Gerrit Jan Schutte is emeritus professor of the Vrije Universiteit Amsterdam, Netherlands and extraordinary professor, Department of History, University of South Africa. He is a specialist in Dutch colonial history and publishes regularly on the history of South Africa. His email address is gj.schutte31@gmail.com 
goewerneur, terwyl sy vader en ander Kaapse familielede in Rusland gebore is. Hul migrasie tussen Europa, Afrika en Asië weerspieël die aard en ontwikkeling van Nederlandse handels- en patrimoniale netwerke. Selfs op die periferie, aan die Kaap en onder Nederlandse uitgewekenes in Rusland, het daardie netwerke geleenthede gebied om oorsese poste te bekom en om met die maatskaplike rangleer te vorder. Die geval van die Swellengrebels wys dat nie net goedere nie, maar ook mense, die reis kon onderneem vanaf Rusland na die Kaap en VOC-beheerde Asië. Patronaatskap het beide ruimtelike en maatskaplike beweeglikheid bevorder. Deur wedersyds voordelige bande met invloedryke patronate, soos Nicolaes Witsen, te smee, kon die Swellengrebel familie hul weg deur die VOC handelsnetwerke baan, en welvaart en aansien behaal in kultureel uiteenlopende samelewings soos Rusland en die Kaap. Die sosiale opgang, identiteitsomvorming en transkontinentale migrasie van die Swellengrebel familie dui op die wesenlikheid van transkontintentale patrimoniale netwerke in die vroeë moderne era.

Sleutelwoorde: Hendrik en Johannes Swellengrebel; migrasie; Nicolaes Witsen; patrimoniale netwerke; patronalisme; patronaatskap; Rusland; sosiale identiteit; opwaartse sosiale mobiliteit; VOC Kaap.

The Swellengrebels have become widely regarded as the most important family at the Cape under Dutch East India Company (VOC) rule who managed "to convert their wealth at the Cape into a position within the Netherlands governing elite". ${ }^{1}$ Hendrik Swellengrebel was the colony's only locally-born governor (between 1739 and 1751), and his descendants continued to influence Cape politics even after his retirement and subsequent emigration to the Netherlands. We do know that several members of this family who lived at the Cape in the first half of the eighteenth century were born in Russia, but in general, Russia's history has not seemed to overlap with the history of the VOC Cape, which is why the precise nature of the Swellengrebels' association with Russia has often been misunderstood. For instance, George McCall Theal referred to the governor's father, Johannes Swellengrebel (1671-1744), as “a Russian”, although at no stage was he a subject of the tsar nor did he develop a Russian ethnic identity. ${ }^{2}$ Moreover, the migration of the Swellengrebels in the late seventeenth and the early eighteenth centuries from Russia to the Cape has been viewed as accidental. ${ }^{3}$ Indeed, it is difficult to see that the family's journey could reveal "the hidden thread" that

1. R. Ross, Status and Respectability in the Cape Colony, 1750-1870: A Tragedy of Manners (Cambridge University Press, Cambridge, 2004), p 15.

2. G.M. Theal, History and Ethnography of Africa South of the Zambesi, Volume 2 (S. Sonnenschein \& Co., London, 1909), p 507.

3. A. Davidson, "Russia and South Africa: Centuries of Contact", in Russia in the Contemporary World. The First Symposium in South Africa at the Centre for Russian Studies (University of Cape Town, 1995), p 95; H.W.J. Picard, Masters of the Castle: A Portrait Gallery of the Dutch Commanders and Governors of the Cape of Good Hope, 16521795 and 1803-1806 (C. Struik, Cape Town, 1972), p 138. 
connected Russia with southern Africa in the eighteenth century. ${ }^{4}$ There was never a Russian settler community in the VOC Cape and no accounts of the Dutch colony written by Russian visitors are known to exist. There were no direct business or transport links between Russia and the Cape. ${ }^{5}$ It was only in the nineteenth century that a Russian ship first anchored in Simon's Town, after the colony had been taken over by the British.

The origins of this family and the ancestry of its Russian and Cape branches have been studied in detail by genealogists. ${ }^{6}$ The Swellengrebels' contribution to the political and social life at the Cape has also been investigated thoroughly. ${ }^{7}$ Johannes Swellengrebel's emigration from Russia to the Cape was documented in his correspondence with his father in Moscow and in his brief autobiography. ${ }^{8}$ However, contextualisation of the Swellengrebels' migration, their adaptation in the host societies and the resulting changes in their social identities may yet provide insight into the patterns of global interaction in the early modern Dutch world. This requires, we suggest, viewing the Cape in the seventeenth and the eighteenth centuries beyond the familiar confines of the VOC history. Dutch trade routes spanned from Russia and the North Atlantic to the Cape of Good Hope, the East Indies and the Americas. The Dutch trade networks reached much further than those of the Dutch East India Company, which is why, for example, progenitors of several European families at the VOC Cape (such as Groenewald or Van Reenen) came from the eastern Baltic areas. The Dutch dominated Russian trade with western Europe in both the Baltic Sea and the White Sea. ${ }^{9}$

4. The expression is borrowed from the title of Apollon Davidson and Irina Filatova's book The Hidden Thread: Russia and South Africa in the Soviet Era (Jonathan Ball, Johannesburg, 2013).

5. B. Gorelik (ed. and trans.), "An Entirely Different World": Russian Visitors to the Cape, 1797-1870 (Van Riebeeck Society, Cape Town, 2015), pp 3, 12; B. Gorelik, "K voprosu o vozniknovenii rossiysko-yuzhnoafrikanskih delovyh svyazey. Allan Bowe, kompanyon Faberge" [On the Emergence of Russian-South African Business Links. Allan Bowe, Fabergé's Business Partner], Journal of the Institute for African Studies, 53, 4, 2020, pp 129-130.

6. Nederland's Patriciaat, 13e Jaargang (Centraal Bureau voor Genealogie en Heraldiek, 'sGravenhage, 1923), pp 372-388.

7. G.J. Schutte, Koloniaal Kaapstad in 1751-1752: Brieven van de Tantes Ten Damme aan hun Nichtjes Swellengrebel (Stichting Zuid-Afrikahuis Nederland, Amsterdam, 2020); G.J. Schutte (red.), Briefwisseling van Hendrik Swellengrebel Jr oor Kaapse Sake, 17781792 (Van Riebeeck-Vereniging, Kaapstad, 1982), p 213; G.J. Schutte (ed.), Hendrik Swellengrebel in Africa: Journals of Three Journeys in 1776-1777 (Van Riebeeck Society, Cape Town, 2018); G.J. Schutte, "Achter de Schermen: Hendrik Swellengrebel en de Kaapse Patriotten", Tydskrif vir Geesteswetenskappe, 59, 4, 2019, pp 562-586.

8. A. Hallema, "Briefwisseling tusschen Hendrik Swellengrebel te Moskou en zijn Zoon Johannes alsmede tusschen Nicolaas Witsen te Amsterdam en Johannes Swellengrebel, 1687-1715", De Navorscher, 80, 1931, pp 27-62.

9. J. de Vries and A. van der Woude, The First Modern Economy: Success, Failure, and Perseverance of the Dutch Economy, 1500-1815 (Cambridge University Press, Cambridge, 1997), p 368. 
We argue that the Swellengrebels' migration between western and eastern Europe and between western Europe, Africa and Asia reflected the development and functioning of Dutch trade and patrimonial networks. Even on the periphery, at the Cape and among Dutch expatriates in Russia, those networks provided opportunities for overseas employment and upward social mobility. The colonial elite's political system at the Cape was grounded in patronage, kinship and matrimonial ties. Local patrimonial networks were integrated into the transcontinental system of kinship and patronage that encompassed the Netherlands and the VOC world. ${ }^{10}$ Patronage was "the fuel" of political life in the Low Countries, a crucial instrument of power and a social asset. $^{11}$

The republic's trade networks not only secured the leadership of Dutch merchants in the Russian trade with western Europe; the modes of patronage employed in the Netherlands and its colonies, including the Cape, were compatible with those that were generally accepted in Russia. Like their Russian counterparts, the republican political elite distributed jobs and resources to its protégés, often preferring loyalty to competence. ${ }^{12}$ In Russia, a patronage mentality had permeated the country's politics, governance and trade for centuries. High nobles were bound together by rivalling patronage networks which, in addition to kinship and marriage alliances, helped them to secure their status in the hierarchy presided by the chief patron, the tsar, and to achieve their socio-political goals. ${ }^{13}$ Local and foreign businesses needed the cooperation of government employees to operate effectively. The Russian state of the seventeenth and eighteenth centuries may be viewed as "patron-clientelism backed by the symbols of divinely ordained absolute monarchy". ${ }^{14}$

Henry Hale applies the term 'patronalism' to “societies where individuals organize their political and economic pursuits primarily around the personalized exchange of concrete rewards and punishments through chains of actual acquaintance". ${ }^{15}$ In his opinion, Russia of the early modern period exemplified a highly patronalistic society, where the most influential factions, those closest to the tsar's

10. N. Worden, "Introduction", in N. Worden (ed.), Cape Town between East and West: Social Identities in a Dutch Colonial Town (Jacana, Johannesburg; Verloren, Hilversum, 2012), pp xv, xix.

11. H.D. Flap, "Patronage: An Institution in its Own Right", in M. Hechter, K.-D. Opp and R. Wippler (eds), Social Institutions: Their Emergence, Maintenance and Effects (Walter de Gruyter, New York, 1990), p 227.

12. K. Boterbloem, The Fiction and Reality of Jan Struys: A Seventeenth-Century Dutch Globetrotter (Palgrave Macmillan, Basingstoke, 2008), pp 33, 197; Flap, "Patronage: An Institution in its Own Right', p 227.

13. R. Crummey, Aristocrats and Servitors: The Boyar Elite in Russia 1613-1689 (Princeton University Press, Princeton, 1983), pp 82-106; N.S. Kollmann, Kinship and Politics: The Making of the Muscovite Political System, 1345-1547 (Stanford University Press, Stanford, 1987), pp 6-7.

14. G. Hosking, "Patronage and the Russian State", The Slavonic and East European Review, 78, 2, 2000, pp 305, 308, 311.

15. H.E. Hale, Patronal Politics: Eurasian Regime Dynamics in Comparative Perspective (Cambridge University Press, New York, 2014), pp 10, 43. 
immediate family, were cemented by pragmatism and headed networks of sub-patrons and clients from various social classes. Societies of the early modern Dutch world, including at the Cape, also had patronalistic features.

We hypothesise that the Swellengrebels used patronage as a conventional method of social advancement in Russia and the Netherlands as well as at the Cape to facilitate their migration within the sphere of the Dutch trade networks, and their adaptation in the host societies. To test this hypothesis, we traced and analysed the Swellengrebels' contribution to Russian foreign trade, the nature and extent of their involvement in the Dutch Russian trade and in patron-client relationships in Europe and Africa as well as the construction and transformation of their social identities.

Among the primary sources we studied were the earliest-known examples of correspondence between residents of Russia and the Cape. The recent historiography shows that Asian and European inhabitants of the colony stayed in contact with their homelands through the Dutch trade networks, contributing to the world of letters that extended across the Atlantic and the Indian oceans. ${ }^{16}$ The correspondence between Heinrich Swellengrebel in Moscow and his son Johannes in Cape Town took an indirect route that was made possible by transcontinental maritime trade. The father's letters travelled from the old Russian capital northwards to the port on the White Sea, westwards to the Low Countries and then southwards aboard VOC vessels.

\section{The Swellengrebels' involvement with Dutch merchant communities in Russia}

The Swellengrebel family spread from the German-speaking town of Stettin, near the Baltic Sea, to other countries and continents along with the expansion of European commerce in the early modern period. The family is of German extraction, and its roots are found in Thuringia. ${ }^{17}$ Erdmann Schwellengrebel, a direct ancestor of the Swellengrebels of Russia and the Cape, spent all his life in Stettin. He had eleven children and worked as a woollen draper and as a dealer in fine cloth. His youngest child, Heinrich, was born in 1626. By the age of seventeen, Heinrich had left his Pomeranian homeland. ${ }^{18}$ Residents of Stettin, which was occupied by Sweden and often contested by the empire's enemies, suffered hardship throughout the Thirty Years' War. It was during that long and devastating conflict that Heinrich Swellengrebel moved to Russia to engage in the Moscow and Archangel trade.

16. See, for example: G. Groenewald, "Southern Africa and the Atlantic World", in D. Coffman, A. Leonard and W. O'Reilly (eds), The Atlantic World, 1450-1850 (Routledge, London and New York, 2015), p 107; S. Newton-King, "Family, Friendship and Survival among Freed Slaves", in Worden (ed.), Cape Town between East and West, pp 153-175; G.J. Schutte (ed.), Seer teder Beminde Heer Vader en Vrouw Moeder! Brieven van de Groninger Familie Fockens in de Oost, 1748-1783 (Verloren, Hilversum, 2014), pp 181183, 186-188; H. Tieken, Between Colombo and the Cape: Letters in Tamil, Dutch and Sinhala Sent to Nicolaas Ondaatje from Ceylon, Exile at the Cape of Good Hope (17281737) (Manohar, Delhi, 2015).

17. Nederland's Patriciaat, 13e Jaargang, p 372.

18. Nederland's Patriciaat, 13e Jaargang, p 384. 
Russia was a "social springboard" for young men from Western Europe who had business acumen and willingness to work in a distant country with a harsh climate, unfamiliar language and (to them) peculiar customs. Russian goods were in demand, therefore the country offered ample opportunities for entrepreneurship. Rich merchants in the Netherlands tended to avoid visiting Russia or sending their close relatives there. Instead, they employed young Dutchmen or Germans from less prosperous families, who either travelled to that country each year or resided there permanently. ${ }^{19}$ From the mid-1630s, Heinrich's elder brother worked in Russia for several months every year representing Amsterdam merchants, the Benarts brothers. Heinrich arrived in Russia in 1643, possibly also as an employee of the Benarts. ${ }^{20}$

In the seventeenth century, the country had no access to the Baltic Sea, therefore Russian merchants brought their wares to Swedish ports to trade with the Dutch and the British. The Baltic trade, the basis of the Netherlands prosperity in the "golden age", exceeded their East Indies trade both in volume and in lucrativeness in the seventeenth century. ${ }^{21}$ However, in the Baltic market, west European merchants were mainly interested in enormous amounts of Polish and Prussian grain and Swedish copper, and the Russian contribution was comparatively small. Greater volumes of Russian goods were shipped to western Europe along the northern coast of Norway.

The town of Archangel (Arkhangelsk) on the White Sea coast, functioned as Russia's "window to the West". It was the main Russian port for ships owned by merchants from western Europe who traded with that country directly. The Netherlands dominated Russian export trade throughout the seventeenth century, sending much-needed silver, weapons and ammunition, fabrics, metalware and luxury commodities to Archangel. ${ }^{22}$ The VOC imports from the East Indies, such as dyes and spices, also reached the Russian shores on Dutch ships and were offloaded at Archangel. ${ }^{23}$ Grain was never among Archangel's main export items: Europeans went there to buy furs, potash, Russian leather, caviar, rhubarb (used as a purgative in Europe), hemp and black pitch.

19. E.H. Wijnroks, Handel tussen Rusland en de Nederlanden, 1560-1640: Een Netwerkanalyse van de Antwerpse en Amsterdamse Kooplieden, handelend op Rusland (Verloren, Hilversum, 2003), pp 374-375.

20. Wijnroks, Handel tussen Rusland en de Nederlanden, p 256.

21. De Vries and Van der Woude, The First Modern Economy, pp 370, 372-373, 415, 494, 498.

22. J.T. Kotilaine, Russia's Foreign Trade and Economic Expansion in the Seventeenth Century: Windows on the World (Brill, Leiden and Boston, 2005), p 263.

23. De Vries and Van der Woude, The First Modern Economy, p 377; N.S. Kollmann, The Russian Empire, 1450-1801 (Oxford University Press, Oxford and New York, 2017), p 189. 
By 1650, Heinrich and Erdmann Swellengrebel were doing business together in Archangel. ${ }^{24}$ It was to their advantage to continue their alliance with the Dutch, whose merchant houses and agents had been operating in Russia for generations. Some of them were appointed as purveyors to the tsar's household or granted charters for export of Russian goods to Europe. Dutch expatriates were known for their loyalty to the tsarist government, the profitability of their commercial activities and the value of their organisational and technological skills for modernisation of Russia's industries, healthcare and armed forces.

In the early modern period, identity was often "situational and commodified", adopted and stated as a means of placing oneself within prestigious and influential social networks. ${ }^{25}$ Identifying with the Dutch allowed a German expatriate like Heinrich to share status with subjects of the dominant trading nation in Europe. Being part of Dutch expatriate communities in Russia provided access to their highly developed kinship and patronage networks, which not only "reinforced and sustained Dutch capitalist development", as they did both in the Netherlands and elsewhere within the reach of its trade routes, but also "forged a sense of belonging to the abstract collective of a nation".26

Heinrich adopted the Dutch version of his German name and omitted the "ch" in his surname (Schwellengrebel); the Russian spelling reflected the original pronunciation until the 1720 s when his son brought it into line. ${ }^{27}$ The style of Heinrich's correspondence indicates that his Dutch was always strongly influenced by his native German. It appears that his association with the Dutch was mostly practical: he identified himself as a German until the end of his life. In his letter of 1693, Heinrich referred to himself and his family as "we, Germans" (wij, duytsen). ${ }^{28}$ His descendants in Russia changed their national identity when it suited their business or familial interests. For instance, his grandson Peter traded as an "English merchant" after Russia awarded privileges to the British subjects in $1734 .{ }^{29}$

24. J.W. Veluwenkamp, Arkhangelsk. Niderlandskiye predprinimateli v Rossii. 1550-1785 [Archangelsk: Dutch Entrepreneurs in Russia, 1550-1785] (ROSSPEN, Moscow, 2006), p 178.

25. K. Wilson, The Island Race: Englishness, Empire, and Gender in the Eighteenth Century (Routledge, London and New York, 2003), p 16.

26. Boterbloem, The Fiction and Reality of Jan Struys, p 178.

27. Russian State Archives of Ancient Acts (hereafter RGADA): f. 150, op. 1, 1706, d. 7, pp 1-2; f. 158, op. 2, 1712, d. 96; 1713, d. 86, pp 1-4.

28. Hallema, "Briefwisseling tusschen Hendrik Swellengrebel te Moskou", p 43.

29. A.V. Dyomkin, Britanskoye kupechestvo v Rossii XVIII veka [British Merchants in 18thcentury Russia] (Institute for Russian History, Russian Academy of Sciences, Moscow, 1998), p 97; and A.V. Dyomkin, Zapadnoyevropeyskoye kupechestvo v Rossii v XVII v. [West European Merchants in Russia in the 17th Century], Volume 2 (Institute for Russian History, Russian Academy of Sciences, Moscow, 1994), pp 101-102, 447, 634. 
European expatriates, whose Protestant faith prevented them from forging matrimonial unions with members of the Russian Orthodox Church, married their coreligionists and formed extended clans which became clients of Russian patronage networks. Marriages within the Protestant communities strengthened their financial situation, their business alliances and their lobbying position. ${ }^{30}$ Among western European merchants in Russia, kinship was more important than nationality as a criterion for entry into their personal networks. ${ }^{31}$ Therefore, marrying a Dutch woman facilitated the construction of Heinrich Swellengrebel's new identity. His wife, Susanna Catharina Ruts, belonged to a prominent Dutch merchant family involved in Russian trade. Another important kinship relationship was forged when Heinrich's brother-inlaw, Johan van Sweeden, who had come to Moscow on a contract with the Ruts family, also became his partner in a new venture that required mobilisation of their patrimonial networks.

A prime reason why the Dutch continued to dominate the Russian foreign trade throughout the seventeenth century was the ability of merchants from the Netherlands to organise steady supplies of west European arms and military equipment. ${ }^{32}$ Dutch trader clans in Russia, as part of the transcontinental Dutch patronage and kinship networks, could procure these goods through their alliances with merchant consortia abroad. ${ }^{33}$ Swellengrebel and Van Sweeden collaborated to import European weapons into Russia for its war with Poland. They negotiated in Hamburg and the Netherlands as official emissaries of the tsar. ${ }^{34}$ To be awarded such a prestigious and lucrative commission, foreign merchants had to be personally known to the monarch and trusted by him and his closest circle.

From 1659 to 1662 , the partners were the largest suppliers of weapons for the Russian army. ${ }^{35}$ In that period, Swellengrebel and Van Sweeden brought into Russia at

30. V.A. Kovrigina, "Inozemniye kuptsy-predprinimateli Moskvy petrovskogo vremeni" [Foreign Merchant-entrepreneurs in the Petrine Moscow], in L.A. Timoshina and I.A. Tikhonyuk (eds), Torgovlya i predprinimatelstvo $v$ feodalnoy Rossii [Trade and Entrepreneurship in Feudal Russia] (Arkheografichesky Tsentr, Moscow, 1994), pp 208-209.

31. Kovrigina, "Inozemniye kuptsy-predprinimateli Moskvy petrovskogo vremeni", pp 208-209.

32. K. Boterbloem, The Dirty Secret of Early Modern Capitalism: The Global Reach of the Dutch Arms Trade, Warfare and Mercenaries in the Seventeenth Century (Routledge, London and New York, 2020), p 168.

33. De Vries and Van der Woude, The First Modern Economy, pp 377-378.

34. N.N. Bantysh-Kamensky, Obzor vneshnikh snosheniy Rossii (po 1800 god) [Overview of Russia's External Relations (until 1800)], Volume 1 ([no publisher] Moscow, 1894), p 185; Kovrigina, "Inozemniye kuptsy-predprinimateli Moskvy petrovskogo vremeni", p 206.

35. Dyomkin, Zapadnoyevropeyskoye kupechestvo $v$ Rossii $v$ XVII v., Volume 1, p 44; Kotilaine, Russia's Foreign Trade and Economic Expansion, p 81; L.D. Popova and J.W. Veluwenkamp (eds), The Dutch in the Russian North in the XVI-XX Centuries (Pomorye State University, Arkhangelsk, 2007), p 270; and Veluwenkamp, Arkhangelsk. Niderlandskiye predprinimateli $v$ Rossii, p 179. 
least 75000 muskets, 30000 carbines, 34000 pairs of pistols as well as swords and shells. ${ }^{36}$ Heinrich drew his brothers into this business. ${ }^{37}$. In exchange for the firearms, the Swellengrebels and Van Sweeden received Russian goods that were sought-after in western Europe. They also recruited veterans of European wars as officers for the modernising Russian army. Among the mercenaries enlisted by Heinrich Swellengrebel was Lodewyck Fabritius, a future Swedish ambassador to Iran. ${ }^{38}$

Russian business was affected by the acute financial crisis in the early 1660s, and Swellengrebel and Van Sweeden went their separate ways. However, their connections among high officialdom in Russia continued to protect their interests. In 1662, Amsterdam merchants failed to pay the partners for their goods. On Swellengrebel and Van Sweeden's request, the authorities searched the homes of the agents of those Dutch merchants in Archangel and confiscated their property. Three years later the dispute remained unresolved, and the Dutch government asked the tsar through a special envoy, Jacob Boreel, to intervene. Despite his strenuous efforts, the Russian authorities' support for Van Sweeden and Swellengrebel in this case was unwavering. ${ }^{39}$

Heinrich Swellengrebel imported and supplied broadcloth to the Russian government in exchange for potash, becoming the principal buyer of this industrial chemical among the European merchants in Russia in $1654 .{ }^{40}$ The country needed this fabric for army uniforms; however, the local production was insufficient. A son of a woollen draper, Heinrich used his family's connections in the textile industry to obtain large quantities of broadcloth, which he continued to import into Russia in the 1660s. His brother George in Amsterdam was a cloth merchant, who had business dealings both with Heinrich and Erdmann in Moscow and with their two merchant brothers in Stettin. ${ }^{41}$

By 1675, Heinrich Swellengrebel's property had become a victim of a blaze. Most structures in Russian cities and towns were made of wood, which caught fire easily. A burning warehouse would often be plundered by neighbours and other residents. In a written statement, Swellengrebel claimed that the "fiery ignition" led to his financial ruin. ${ }^{42}$ In desperation, he appealed to the most powerful patron in the

36. Veluwenkamp, Arkhangelsk: Niderlandskiye predprinimateli v Rossii, p 179.

37. Dyomkin, Zapadnoyevropeyskoye kupechestvo v Rossii v XVII v., Volume 1, p 44.

38. L. Fabritius, "Zapiski" [A memoir], in Zapiski inostrantsev o vosstanii Stepana Razina [Foreign Memoirs of the Stepan Razin Insurrection], Volume 1 (Nauka, Leningrad, 1968), p 14.

39. Bantysh-Kamensky, Obzor vneshnikh snosheniy Rossii (po 1800 god), pp 186-187; Boterbloem, The Dirty Secret of Early Modern Capitalism, p 208; N. Witsen, Moscovische reyse, 1664-1665: journaal en aentekeningen, Deel I (Martinus Nijhoff, 's-Gravenhage, 1966), p 38 (XXXVIII).

40. Kotilaine, Russia's Foreign Trade and Economic Expansion, p 263.

41. Hallema, "Briefwisseling tusschen Hendrik Swellengrebel te Moskou", p 28; Nederland's Patriciaat, 13e Jaargang, p 382.

42. Dyomkin, Zapadnoyevropeyskoye kupechestvo v Rossii v XVII v., Volume 1, p 116. 
country: the tsar. After an audience with the monarch, in appreciation of his earlier services to the Treasury, Swellengrebel was appointed guardian of the Armoury. ${ }^{43} \mathrm{As}$ a salaried employee, Swellengrebel oversaw the workings of large government stores of firearms and ammunition, and repair shops opposite the Kremlin. In 1687, when the contents of the stores were moved inside the Kremlin, the 61-year-old Heinrich Swellengrebel was dismissed. ${ }^{44} \mathrm{He}$ spent the rest of his life in retirement.

Heinrich's daughters married European merchants in Moscow. His eldest son, Balthasar, emigrated to the Netherlands and became a merchant in Amsterdam. The second son, Hendrik Swellengrebel, remained in Russia. Like his father, he identified himself as Dutch, used the Dutch version of his name, spoke Dutch at home and married a Dutch woman, Anna Geertruida Cannegieter.

Hendrik was a Russian agent for prominent Dutch merchant families, including the Leeuws. He also traded independently, supplying expensive western European textiles to the Russian court and nobility.45 In the early eighteenth century, the Swellengrebels were among the few Dutch merchant families represented in Archangel who had settled in Russia before Peter I came to power. ${ }^{46}$ Thanks to his family's long presence in the country and contacts with the royal court, Hendrik Swellengrebel held government charters and concluded ordinary contractor agreements for the supply of Russian goods with his Russian counterparts despite the official ban on such contracts in the early 1700s. Those privileges were granted arbitrarily by patrons among high officialdom. ${ }^{47}$ Russian monarchs were known to elevate foreigners whom they knew personally, neglecting traditional hierarchies. ${ }^{48}$ Heinrich Swellengrebel was received by Tsar Feodor III and given a job in the civil service in 1676. Heinrich's son, Hendrik, was favoured by Peter I. During the Great Northern War, when the young merchant proposed to marry Catharina Barbara Cnipercrona, a daughter of the former Swedish resident, she was kept hostage in Russia as a family member of an enemy representative. The tsar issued a special decree releasing Hendrik's fiancée on parole. ${ }^{49}$

43. RGADA, f. 150, op. 1, 1676, d. 2, p. 5; Dyomkin, Zapadnoyevropeyskoye kupechestvo $v$ Rossii $v$ XVII v., Volume 2, c. 52.

44. $\quad$ Staraya Moskva (Old Moscow), Volume 2 (Moscow, 1914), pp 1-10.

45. Hallema, "Briefwisseling tusschen Hendrik Swellengrebel te Moskou”, p 51; Nederland's Patriciaat, 13e Jaargang, $\mathrm{p}$ 385; Veluwenkamp, Arkhangelsk. Niderlandskiye predprinimateli $v$ Rossii, pp 207-208, 212.

46. V.N. Zakharov, Zapadnoyevropeyskiye kuptsy v rossiyskoy torgovle XVIII veka [West European Merchants in the Russian Trade of the 18th Century] (Nauka, Moscow, 2005), p 52.

47. Hosking, "Patronage and the Russian State", pp 311-312; Istoriya kratkaya rossiyskoy torgovli [A Brief History of Russian Trade] ([no author, no publisher], Moscow, 1788), p 132; Zakharov, Zapadnoyevropeyskiye kuptsy v rossiyskoy torgovle XVIII veka, pp 344, 424.

48. L. Hughes, Russia in the Age of Peter the Great (Yale University Press, New Haven and London, 1998), pp 416-417; Kovrigina, "Inozemniye kuptsy-predprinimateli Moskvy petrovskogo vremeni", p 206.

49. Doklady i prigovory, sostoyavshiyesya v Pravitelstvuyutshem Senate v tsarstvovaniye Petra Velikogo ... [Reports and Resolutions of the Governing Senate in the Reign of Peter 
In the spirit of reciprocity, as befits patron-protégé relations, Hendrik Swellengrebel named his son "Peter" after the monarch, who was also recorded as the boy's godfather. 50

By the 1720s, the Dutch merchants' grip on Russian export trade had weakened. Peter I restricted the foreign trade through Archangel, where the Swellengrebels had had a firm foothold for over half a century, in favour of the new port of Saint Petersburg with its direct access to the Baltic Sea. This prompted Hendrik to follow in his father's footsteps to work in the civil service. The family moved to Saint Petersburg where Hendrik Swellengrebel was appointed councillor of the Collegium of Commerce, the government institution in charge of internal and external trade of the Russian Empire. His last known position, before his death in 1742, was ober-kommissar in the Saint Petersburg Treasury; this civil service rank was equivalent to the colonel's in the Russian army. 51

\section{Nicolaes Witsen's patronage and migration to the VOC Cape}

Heinrich Swellengrebel's third son, Johannes, the future founder of the South African branch of the family, was born in Moscow in 1671. His mother, Heinrich's second wife Elisabeth Fademrecht, was a daughter of the Lutheran pastor in that city. At the age of seventeen, Johannes travelled to Vologda and Archangel for business: his father Heinrich encouraged him to learn a trade to make a living in the future. ${ }^{52}$ Having left in 1688, Johannes received training in Archangel under his brother-in-law, a Moscowborn Dutch merchant Johannes Bacheracht. Afterwards, Swellengrebel went to Western Europe. He was employed as junior clerk by his uncle in Hamburg and by Otto Rückert, a prominent merchant from Leipzig. In 1690, Johannes moved to Amsterdam, where his brother, Balthasar, was already living and trading.

the Great], Volume IV (1714), part II (July-December) (Imperial Academy of Sciences, Saint Petersburg, 1883), pp 688-689; S.A. Kozlov, Russkiye plenniye Velikoy Severnoy voyny, 1700-1721 [Russian Prisoners of the Great Northern War, 1700-1721] (Istoricheskaya Illyustratsiya, Saint Petersburg, 2011), p 190.

50. Nederland's Patriciaat, 13e Jaargang, p 386.

51. Sbornik Imperatorskogo russkogo istoricheskogo obshtshestva [Almanac of the Imperial Russian Historical Society], Volume 114 (Yuryev, 1902), pp 340, 367; Russkiye diplomaticheskiye agenty v Londone v XVIII v. [Russian Diplomatic Agents in London in the 18th Century], Volume II (Warsaw, 1897), p 318; Senatskiy arkhiv [Senate Archives], Volume IV (July-September 1741) (Governing Senate, Saint Petersburg, 1891), p 365.

52. H. Swellengrebel, Moscow - his son, J. Swellengrebel, Archangel, 1687, in Hallema, "Briefwisseling tusschen Hendrik Swellengrebel te Moskou", p 31. 
Johannes spent another year as a junior clerk with the timber-merchant business of his aunt, a member of the Fademrecht family. The company was involved in the Russian trade. ${ }^{53}$ However, Dutch commerce had already started to shift its focus from its traditional markets to other continents, primarily Asia where the VOC became the main European commercial and political force. The share of the commodities sourced in the East Indies grew steadily, proportionately to the diminishing significance of the grain trade. In the following decades, merchants from the Netherlands came to specialise in re-export of colonial goods rather than on the distribution of European products. The Baltic grain trade lost its supremacy, while the VOC made larger contributions to the economy of the Netherlands. Most of the spices, silk and cotton, tea, coffee and porcelain from East, South and Southeast Asia delivered to the Baltic ports, including Saint Petersburg in Russia, arrived on Dutch ships. ${ }^{54}$

In highly patronalistic societies, material welfare was achieved by belonging to a coalition that had access to resources and the right to distribute them. Securing a new job implied finding another patron, starting a mutually beneficial relationship with him and joining his network that could be mobilised to achieve one's goals. ${ }^{55}$ Therefore, Heinrich Swellengrebel, guided by his experiences in Russia, urged his son to seek a permanent and trustworthy benefactor in western Europe. ${ }^{56}$ Thanks to Balthasar, Johannes Swellengrebel was introduced to one of the most powerful patrons in the Netherlands, Nicolaes Witsen. ${ }^{57}$ It was probably Witsen who persuaded him to join the VOC service. In December 1691, Johannes sailed for the Cape of Good Hope. Throughout the following two decades, the patron's presence in the life of Johannes was felt strongly even though they lived on different continents.

It could well be that Witsen became acquainted with the Swellengrebels in 1665, when he visited Moscow as part of Jacob Boreel's retinue. The Witsen family had traded with Russia since the late sixteenth century, but the young Nicolaes seemed more interested in information about Russia's judicial and political system, the people and their customs, than in matters of commerce. Among his interviewees was Van Sweeden, Heinrich Swellengrebel's former business partner. ${ }^{58}$ That journey sparked Witsen's deep interest in Russia, culminating in his comprehensive book on Siberia, the scholarly work of his life, Noord en Oost Tartaryen (Amsterdam 1692; 1705, enlarged edition).

53. Hallema, "Briefwisseling tusschen Hendrik Swellengrebel te Moskou", pp 57-58; K. Heeringa, "Overzicht van de betrekkingen van Rusland tot Nederland tot aan het jaar 1800, door N.N. Bantyš-Kamenskij, medegedeeld door Dr K. Heeringa”, Bijdragen en Mededeelingen van het Historisch Genootschap. 51, 1930, p 80.

54. De Vries and Van der Woude, The First Modern Economy, pp 429, 437, 464, 481-483, 498, 500-501.

55. Flap, "Patronage: An Institution in its Own Right", p 235; Hale, Patronal Politics: Eurasian Regime Dynamics in Comparative Perspective, p 61.

56. Hallema, "Briefwisseling tusschen Hendrik Swellengrebel te Moskou", p 34.

57. See Hallema, "Briefwisseling tusschen Hendrik Swellengrebel te Moskou", p 39 note 5.

58. Witsen, Moscovische reyse, 1664-1665, Deel II, pp 373-388. 
From the late seventeenth to the early eighteenth century, Witsen represented a link between Russia and the Cape of Good Hope. The Witsen family was among the founders of the VOC, and Nicolaes, like his father, joined the Heren XVII, the Company's directors. The high opinions of the Amsterdam treasurer and burgomaster, the Bewindhebber of the VOC (and a friend of Peter I) were influential at the meetings of his city council, at the States General and with the Company's directors.

In his letters to Johannes Swellengrebel at the Cape, Witsen, an esteemed Dutch scholar and administrator, referred to the Cape official, thirty years his junior, as his "special friend" (bijsondere vrint). Evidently, Johannes was presented to Witsen while working in Amsterdam in the year before his departure for the Cape, but they never saw each other afterwards. Nevertheless, they carried on their correspondence at least until 1715, two years before Witsen's death. In such a "lopsided friendship", as patronage ties are sometimes known, VOC administrators provided opportunities to their clients, who reciprocated by expressing their gratitude with presents and letters of appreciation, by pursuing the patron's policies and by supplying useful information. ${ }^{59}$

What services did Witsen expect from his protégé in exchange for his endorsement? He used his influential position to obtain information and objects that could broaden the contemporary European knowledge of the outside world. Members of his personal network contributed data that enabled Witsen to produce detailed maps and comprehensive studies of the Asian part of Russia without setting foot there. Similarly, as a director of the VOC, he read and used reports compiled by the company's officials at the Cape and requested further information from them. Witsen was known to help talented young men, including astronomer and ethnologist Peter Kolbe, to secure VOC postings and recommended them for promotion. The Van der Stel family at the Cape was also part of Witsen's patrimonial network. It is known that Governor Simon van der Stel favoured Witsen's protégés and the newly appointed Governor Willem Adriaen van der Stel named a mountain range in the Tulbagh Valley "Witsenbergen", probably in gratitude for the director's endorsement.60

Perhaps Johannes Swellengrebel, having established himself at the Cape, also became Witsen's informant in the age when production of knowledge in geography and natural history depended on patronage networks for data collection. During the Expansion Age, the size of the VOC nearly doubled. In earlier times it was regarded as an unattractive employer because of its relatively low salaries and the high mortality rate in its Asian colonies. and aboard its East Indiamen. However, with the mounting unemployment in the Netherlands, the company was recruiting most of its personnel

59. J. Pitt-Rivers, The People of the Sierra (Criterion Books, New York, 1954), p 140; F. Lequin, "Het personeel van de VOC in Azië en de achttiende eeuw eeuw, meer in het bijzonder in de vestiging Bengalen", PhD thesis, Leiden University, 1982, pp 44, 46, 6467, 93; Schutte, Seer teder Beminde Heer Vader en Vrouw Moeder! pp 14, 31.

60. G. Groenewald, "To Leibniz, from Dorha: A Khoi Prayer in the Republic of Letters", Itinerario: International Journal on the History of European Expansion and Global Interaction, 28, 1, 2004, pp 34-35, 46. 
among the Dutch. ${ }^{61}$ The VOC increased its labour force bound for Asia, while the size and the capacity of the company's fleet was growing. Most employees entered the service of the VOC as seamen and soldiers, but there was also work for craftsmen, clerks and junior officials (onderkooplieden).

The VOC Cape was a multicultural, multilingual and multiracial society, incorporating immigrants from various parts of Africa, Asia and Europe. The position of settlers in colonial Cape Town society was determined not by their ethnicity or place of birth but largely by their legal status (free or enslaved), their relation to the VOC (company personnel or free-burgher), their religion (Dutch Reformed or other) and their financial situation. Accordingly, at the Cape, career advancement depended on education, social background and efficiency as well as on kinship and patronage of local high officials and VOC administrators in Amsterdam. ${ }^{62}$ On Heinrich Swellengrebel's request, Witsen supplied Johannes Swellengrebel with letters of recommendation. ${ }^{63}$ The endorsement drew the Cape governor's attention to Johannes, who was swiftly promoted to the post of assistant to the general secretary.

As a VOC clerk, Swellengrebel went to Madagascar to buy slaves and later served as a bookkeeper on the company's ships in the war against the French fleet near India and Ceylon. On his return to the Cape, he married Johanna, a daughter of Hieronimus Cruse, a colonial explorer and commander of the local garrison. Johannes was appointed to the Council of Policy (1698) and his marriage made him a brother-in-law of two members of that council.

\section{Advancement within patrimonial networks at the Cape}

The VOC protected the political dominance of the Dutch at the Cape by restricting the promotion of Lutherans, mostly Germans. To be appointed to the Council of Policy, as was Johannes Swellengrebel, a practising Lutheran needed endorsement from the Heren XVII, which could be obtained only through influential patrons in Amsterdam. ${ }^{64}$ Furthermore, promotion to the higher VOC ranks was costly. It required influential patrons who had to be rewarded with presents that matched their status in the company's hierarchy. ${ }^{65}$ Johannes Swellengrebel could afford such gifts because he had been granted extensive farmland in the Tijgerberg area and along the Liesbeeck River.

At the Cape, Johannes Swellengrebel encountered competing patrimonial factions which resembled those among the ruling elites in Russia and the Netherlands. The system preserved the monopoly of foreign-born officials over the elite positions in colonial administration. The higher officials tended to regard their residence at the

61. De Vries and Van der Woude, The First Modern Economy, pp 437, 450-453.

62. G.J. Schutte, De Nederlandse Patriotten en de koloniën. Een onderzoek naar hun denkbeelden en optreden 1770-1800 (Tjeenk Willink, Groningen, 1974), pp 32-38.

63. H. Swellengrebel, Moscow - J. Swellengrebel, Cape Colony, 1693, in Hallema, "Briefwisseling tusschen Hendrik Swellengrebel te Moskou", p 40.

64. Ross, Status and Respectability in the Cape Colony, 1750-1870, p 103.

65. See F.S. Gaastra, Scheepsvolk (Universiteit Leiden, Leiden, 2010). 
Cape as temporary, hoping for career opportunities at the power-centres of the VOC world. The governing elite at the Cape consisted of expatriates who used their connections across the VOC transcontinental empire. Their cultural and social identities were Dutch while their outlook was formed by their experiences in various parts of Europe and Asia.

Born and brought up in an expatriate Dutch community, Johannes Swellengrebel viewed the Cape official elite, "the least localised segment of the population", as his reference group. ${ }^{66}$ Like the VOC regents in the Netherlands or the high officials in the Russian government, elite factions at the Cape built up a clientele among the lower ranks. Involvement in these patronage networks gave Swellengrebel access to advantageous appointments and land grants. Cape elites included leading merchants and farm owners who were linked to high officials of the VOC by marriage alliances and property acquisition. As a high-ranking VOC official, Swellengrebel aligned himself with the Van der Stel family and the VOC networks, which were closed to most European colonists at the Cape. He played an important role in the discrediting and dismissal of the acting governor Willem Helot (1710-1714). ${ }^{67}$

By contrast, the evolving Cape burgher identity prioritised status and wealth rather than links with the metropole. Free burghers had already started forming their own kinship and patronage connections which sometimes came into conflict over political and economic rights with the patrimonial networks encompassing VOC elites in the Netherlands and in the colonies. ${ }^{68}$ In 1707, this led to the deposition of the Governor Willem Adriaan van der Stel, Johannes Swellengrebel's patron in the colony, on charges of corruption and profiteering.

Similar accusations were brought against Swellengrebel. While in the company's service, he accumulated vast landholdings and engaged in wine production, which was forbidden to the company's staff. ${ }^{69}$ Witsen, who made a habit of praising Johannes before the Heren XVII whenever possible, was unable to protect him this time. ${ }^{70}$ The effectiveness of patronage in the VOC had its limits. To avoid the fate of Van der Stel, who was forced to sell his property at the Cape, Swellengrebel resigned from the Council of Policy and left the company's service in 1716. His resignation drew him

66. R. Ross and A. Schrikker, "The VOC Official Elite", in Worden (ed.), Cape Town between East and West, pp 26-44.

67. A.J. Böeseken (red.), Resolusies van die Politieke Raad, Deel IV (Staatsdrukker, Kaapstad, 1962), pp 387-400.

68. K. Ward, "Patrimonialism, Imperialism and Colonialism at the Cape of Good Hope under Dutch East India Company Rule, c. 1652-1795", in M.M. Charrad and J.P. Adams (eds), Patrimonial Capitalism and Empire (Emerald Group, Bingley, 2015), pp 91-92, 105.

69. G.J. Schutte (ed.), Hendrik Cloete, Groot Constantia and the VOC, 1778-1799, Documents from the Swellengrebel Archive (Van Riebeeck Society, Cape Town, 2003), p 5.

70. N. Witsen, Amsterdam - J. Swellengrebel, Cape Colony, 1714 and 1715, in Hallema, "Briefwisseling tusschen Hendrik Swellengrebel te Moskou", pp 61-62; F. Valentijn, Beschryvinge van de Kaap der Goede Hoope, Deel I (Van Riebeeck Society, Cape Town, 1971), p 192 (note). 
closer to the social worlds of localised elites, particularly through his marriages to Cape women belonging to the colonial upper classes of VOC managers and settled free burghers of German and of Dutch origin. At the same time, he maintained links to the patrimonial networks of the company's elite in the metropole. Johannes named his son Hendrik (1700-1760) after his own father, who had passed away in Moscow a year before. The wealth accumulated by Johannes and his family's influence exerted through their participation in the Dutch networks of kinship and patronage, enabled Hendrik Swellengrebel to carve out an extraordinary career in the VOC by calling upon those ties. Having entered the company's service at the age of thirteen, he soon rose through the ranks to become the governor of the Cape (1739). He showed his gratitude to the VOC directors with annual shipments of Constantia wine. ${ }^{71}$

\section{Changing social identities}

Tracing the construction of Johannes Swellengrebel's identity through his cultural practices shows that he considered himself a Dutchman of German extraction. Even before his arrival at the Cape, his primary native language was Dutch, in which language he corresponded with his father. This indicates that his cultural identity was also Dutch. While Heinrich's association with the Dutch was largely pragmatic, Johannes, through his long participation in their networks of kinship, patronage and power, incorporated the Netherlands' national identity into his personal identity.

Meanwhile, his ethnic identity probably remained German-oriented. Although Johannes Swellengrebel was kin to Dutch families through his second and third marriages, his first wife (the governor's mother) was of German descent. Religious identity could also serve as a marker of ethnicity at the Cape, where Lutherans were predominantly German. Johannes turned to the Dutch Reformed Church for the solemnisation of his marriages and the baptism of his children, because there was no Lutheran church in the colony until 1780. Yet two years before his death, in 1742 , Johannes was among the signatories to a petition to the Council of Policy for the establishment of the first Lutheran congregation in Cape Town.

No evidence has been found to suggest that his son Hendrik retained German elements in his personal identity. Hendrik married the daughter of a well-to-do Dutch chief surgeon and became a successful farmer in 1708. Steadfastly loyal to the Netherlands and his Calvinist faith, Hendrik was a full member and former elder of the Reformed Church. The petition for a Lutheran congregation was submitted while Hendrik Swellengrebel was the Cape governor. Although it was signed by his father, he rejected it. ${ }^{72}$ The first church of that denomination opened long after his term in office had ended.

71. Schutte (ed.), Hendrik Cloete, Groot Constantia and the VOC, 1778-1799, p 26.

72. G.C. de Wet (red.), Resolusies van die Politieke Raad, Deel VII (Staatsdrukker, Johannesburg, 1971), 14 Februarie 1742, 19 Junie 1742. 
Several other direct descendants of Heinrich Swellengrebel set foot at the Cape in the period from 1700 to 1730s, during the VOC's Expansion Age. It was a form of chain migration: European colonists who prospered at the Cape, like Johannes Swellengrebel, were followed by their family members. The most prominent of them was Johannes's nephew, Sergius. The eldest son of Balthasar Swellengrebel, he arrived from the Netherlands in 1712, left in 1722 and returned to the colony in 1750. Sergius died at the Cape in 1760, having served as deputy governor (secunde) under Hendrik Swellengrebel's successor.

Heinrich's Russian-born grandchildren, Thomas Swellengrebel and Johannes Bacheracht, settled at the Cape in 1739 and occupied mid-level clerical positions for several years until their transfer to the VOC's colonies in Asia (Batavia and Bengal). ${ }^{73}$ Johannes Swellengrebel's younger brother, Benjamin, born and brought up in Moscow, was hired by the VOC as a midshipman. He sailed to the Cape in 1709. However, his stay in the colony was brief. Benjamin obtained a clerical position in the East Indies in 1710 and died in Batavia soon afterwards. ${ }^{74}$ Hendrik Swellengrebel's broad patrimonial network at the Cape was taken over by his brother-in-law, Rijk Tulbagh, who succeeded him as governor in 1751 . The Tulbagh-Swellengrebel clan continued to dominate Cape politics until Rijk Tulbagh's death in 1771.

It was customary among VOC elite families to "return home" from the colonies at the end of their careers with the company. ${ }^{75}$ Hendrik Swellengrebel left the Cape once he retired from the governor's post; his sons had moved to the Low Countries even earlier. ${ }^{76}$ In the case of Hendrik, the notion of the Netherlands as "home" was symbolic: neither he, nor his parents and grandparents were born there. However, the national identity and considerations of status and prestige dictated the Kaapenaar's decision to emigrate. He spent the rest of his life in retirement as a country gentleman on his estate outside Utrecht.

The Swellengrebel family maintained its ties with the ruling elites in the Netherlands and patrimonial networks at the Cape. To the governor's son and namesake, the Cape was 'mijn vaderland' (my birthplace), while the Netherlands for him was 'het vaderland', 'patria', the object of his allegiance as part of his national identity. ${ }^{77}$

73. Nederland's Patriciaat, 13e Jaargang, p 386; Schutte, Koloniaal Kaapstad, pp 37-38.

74. C.C. de Villiers and C. Pama, Genealogies of Old South African Families (A.A. Balkema, Cape Town, 1966), p 962.

75. Ward, "Patrimonialism, Imperialism and Colonialism at the Cape of Good Hope", p 104.

76. Schutte (ed.), Hendrik Cloete, Groot Constantia and the VOC, 1778-1799, p 7.

77. H. Swellengrebel to J.E. Huydecoper, 1774: “.... mij niets aangenamer is, na mijne geringe vermogens iets kan toebrengen tot nut van mijn Vaderland [the Cape]; ... een mistasting in de actuele situatie der colonie van de nadeligste gevolgen sijn soo voor haar [the Cape] als voor 't vaderland [the Netherlands]. Compare with H. Swellengrebel to Hendrik Cloete 12 December 1785: daar mij geen vooruitzicht om mijn Vaderland [the Cape] eens weder te komen besoeken overschiet. Schutte (red.), Briefwisseling van Hendrik Swellengrebel Jr oor Kaapse sake, 1778-1792, pp 213, 220. 
Like all servants of the VOC who moved to the Netherlands from the colonies, he "repatriated". Hendrik Swellengrebel junior travelled widely in the colony in 17761777. He functioned as an informal adviser, mediator and critic of both the Cape Patriot Movement (from 1778) and the VOC officials at the Cape and in Amsterdam, using his extensive network of correspondents in the colony and the metropole. The company administration saw him as a successor to Governor Baron Joachim van Plettenberg at the Cape, but his appointment was vetoed by the then stadtholder of the republic, William V.78

\section{Conclusion}

The Swellengrebel family was involved in the transcontinental Dutch trade networks even before they settled at the Cape. In the seventeenth and the early eighteenth centuries, Russia had no direct trade or transport links with the VOC world outside Europe. Migration between Russia and the Cape was minimal and the only known documented case is that of the Swellengrebels. However, Russia and the VOC world were connected by the Dutch trade networks that extended from Europe to South Asia and the Southern Hemisphere. Since the seventeenth century, large quantities of products from the Dutch East Indies reached Russia on Dutch ships via the Cape and the Netherlands. It is reasonable to assume that Russian exports were also shipped to various destinations in the VOC world via the Dutch entrepot.

As we have demonstrated, the case of the Swellengrebels shows that not only goods but also people could make their way from Russia to the Cape and the VOC Asia using the Dutch trade networks. They moved via the Netherlands, a hub for migrant labour from across the continent. It was part of the transmarine and transcontinental migration from north-western Europe and the settlement of the "new worlds".

The Swellengrebels understood and used patronage expertly. To do so became an extraordinarily effective method of advancement in patronalistic societies. They were involved in patrimonial networks at the Cape as well as in Russia and the Netherlands and these provided the Swellengrebels with lucrative career and business opportunities as well as access to the ruling elites. Their example demonstrates that patronage enabled both spatial and upward social mobility. Keeping mutually beneficial relations with influential patrons, members of the Swellengrebel family navigated their way within the Dutch trade networks and achieved prosperity and high status in such culturally diverse societies as Russia and the Cape.

For the Swellengrebels, both Russia and the Cape were political and economic peripheries. They had a loyalty for the networks linked to elites in the Netherlands, Europe's foremost trading nation. They never lost sight of that connection, which is why they did not align themselves with local elites in Moscow or Cape Town. From the mid-seventeenth century, after Heinrich Swellengrebel joined the Dutch expatriate networks in Russia, their national identities were Dutch, although their ethnic

78. See Schutte (ed.), Hendrik Swellengrebel in Africa; and Schutte, "Achter de schermen". 
identities remained German at least in the first two generations. At the Cape, they maintained their social identity through association with the VOC ruling elite, their patrons in Amsterdam. In turn, their fidelity was rewarded with Hendrik Swellengrebel's appointment as governor. The social advancement, identity transformations and transcontinental migrations of the Swellengrebel family therefore clearly demonstrate the materiality of transcontinental patrimonial networks in the early modern period.

\section{REFERENCES}

Bantysh-Kamensky, N.N., Obzor vneshnikh snosheniy Rossii (po 1800 god) [Overview of Russia's External Relations (until 1800)], Volume 1 ([no publisher], Moscow, 1894).

Böeseken, A.J. (red.), Resolusies van die Politieke Raad, Deel IV (Staatsdrukker, Kaapstad, 1962).

Boterbloem, K., The Dirty Secret of Early Modern Capitalism: The Global Reach of the Dutch Arms Trade, Warfare and Mercenaries in the Seventeenth Century (Routledge, London and New York, 2020).

Boterbloem, K., The Fiction and Reality of Jan Struys: A Seventeenth-Century Dutch Globetrotter (Palgrave Macmillan, Basingstoke, 2008).

Crummey, R., Aristocrats and Servitors: The Boyar Elite in Russia 1613 - 1689 (Princeton University Press, Princeton, 1983).

Davidson, A., "Russia and South Africa: Centuries of Contact", in Russia in the Contemporary World. The First Symposium in South Africa at the Centre for Russian Studies (University of Cape Town, Cape Town, 1995).

Davidson, A., and Filatova, I., The Hidden Thread: Russia and South Africa in the Soviet Era (Jonathan Ball, Johannesburg, 2013).

De Villiers, C.C, and Pama, C., Genealogies of Old South African Families (A.A. Balkema, Cape Town, 1966).

De Vries, J., and Van der Woude, A., The First Modern Economy: Success, Failure, and Perseverance of the Dutch Economy, 1500-1815 (Cambridge University Press, Cambridge, 1997).

De Wet, G.C. (red.), Resolusies van die Politieke Raad, Deel VII (Staatsdrukker, Johannesburg, 1971).

Doklady i prigovory, sostoyavshiyesya $v$ Pravitelstvuyutshem Senate $v$ tsarstvovaniye Petra Velikogo ... [Reports and Resolutions of the Governing Senate in the Reign of Peter the Great], Volume IV (1714), part II (July - December) (Imperial Academy of Sciences, Saint Petersburg, 1883).

Dyomkin, A.V., Britanskoye kupechestvo v Rossii XVIII veka [British Merchants in 18thcentury Russia] (Institute for Russian History, Russian Academy of Sciences, Moscow, 1998).

Dyomkin, A.V., Zapadnoyevropeyskoye kupechestvo v Rossii v XVII v. [West European Merchants in Russia in the 17th Century] (Institute for Russian History, Russian Academy of Sciences, Moscow, 1994). 
Fabritius, L., "Zapiski” [A memoir], in Zapiski inostrantsev o vosstanii Stepana Razina [Foreign Memoirs of the Stepan Razin Insurrection] (Nauka, Leningrad, 1968).

Flap, H.D., "Patronage: An Institution in its Own Right", in Hechter, M, Opp, K.-D. and Wippler, R (eds), Social Institutions: Their Emergence, Maintenance and Effects (Walter de Gruyter, New York, 1990), pp 225-243.

Gaastra, F.S., Scheepsvolk (Universiteit Leiden, Leiden, 2010).

Gorelik, B. (ed. and trans.), "An Entirely Different World": Russian Visitors to the Cape, 1797-1870 (Van Riebeeck Society, Cape Town, 2015).

Gorelik, B., "K voprosu o vozniknovenii rossiysko-yuzhnoafrikanskih delovyh svyazey. Allan Bowe, kompanyon Faberge" [On the emergence of Russian-South African business links. Allan Bowe, Fabergé's business partner], Journal of the Institute for African Studies, 53, 4 (2020), pp 129-141.

Groenewald, G., "Southern Africa and the Atlantic World", in Coffman, D., Leonard, A. and O'Reilly, W. (eds), The Atlantic World, 1450-1850 (Routledge, London and New York, 2015), pp 100-116.

Groenewald, G., "To Leibniz, from Dorha: A Khoi Prayer in the Republic of Letters", Itinerario: International Journal on the History of European Expansion and Global Interaction, 28, 1 (2004), pp 29 - 48.

Hale, H.E., Patronal Politics: Eurasian Regime Dynamics in Comparative Perspective (Cambridge University Press, New York, 2014).

Hallema, A., "Briefwisseling tusschen Hendrik Swellengrebel te Moskou en zijn Zoon Johannes alsmede tusschen Nicolaas Witsen te Amsterdam en Johannes Swellengrebel, 1687-1715", De Navorscher, 80 (1931), pp 27-62.

Heeringa, K., "Overzicht van de Betrekkingen van Rusland tot Nederland tot aan het jaar 1800, door N.N. Bantyš-Kamenskij, Medegedeeld door Dr K. Heeringa”, Bijdragen en Mededeelingen van het Historisch Genootschap, 51 (1930), pp 35103.

Hosking, G., "Patronage and the Russian State", The Slavonic and East European Review, 78, 2 (2000), pp 301-320.

Hughes, L., Russia in the Age of Peter the Great (Yale University Press, New Haven and London, 1998).

Istoriya kratkaya rossiyskoy torgovli [A Brief History of Russian Trade] ([no author; no publisher], Moscow, 1788).

Kollmann, N.S., Kinship and Politics: The Making of the Muscovite Political System, 13451547 (Stanford University Press, Stanford, 1987).

Kollmann, N.S., The Russian Empire, 1450-1801 (Oxford University Press, Oxford and New York, 2017).

Kotilaine, J.T., Russia's Foreign Trade and Economic Expansion in the Seventeenth Century: Windows on the World (Brill, Leiden and Boston, 2005).

Kovrigina, V.A., "Inozemniye kuptsy-predprinimateli Moskvy petrovskogo vremeni" [Foreign Merchant-entrepreneurs in the Petrine Moscow], in L.A. Timoshina and I.A. Tikhonyuk (eds), Torgovlya i predprinimatelstvo $v$ feodalnoy Rossii [Trade and Entrepreneurship in Feudal Russia] (Arkheografichesky Tsentr, Moscow, 1994), pp 190-213. 
Kozlov, S.A., Russkiye plenniye Velikoy Severnoy voyny, 1700-1721 [Russian Prisoners of the Great Northern War, 1700-1721] (Istoricheskaya Illyustratsiya, Saint Petersburg, 2011).

Lequin, F., "Het personeel van de VOC in Azië en de achttiende eeuw eeuw, meer in het bijzonder in de vestiging Bengalen", PhD thesis, Leiden University, 1982.

Nederland's Patriciaat, 13e Jaargang (Centraal Bureau voor Genealogie en Heraldiek, 's-Gravenhage, 1923): Swellengebel.

Newton-King, S., "Family, Friendship and Survival among Freed Slaves", in Worden, N. (ed.), Cape Town between East and West: Social identities in a Dutch Colonial Town (Jacana, Johannesburg; Verloren, Hilversum, 2012), pp 153-175.

Picard, H.W.J., Masters of the Castle: A Portrait Gallery of the Dutch Commanders and Governors of the Cape of Good Hope, 1652-1795 and 1803-1806 (C. Struik, Cape Town, 1972).

Pitt-Rivers, J., The People of the Sierra (Criterion Books, New York, 1954).

Popova, L.D., and Veluwenkamp, J.W. (eds), The Dutch in the Russian North in the XVI XX Centuries (Pomorye State University, Arkhangelsk, 2007).

Ross, R., Status and Respectability in the Cape Colony, 1750-1870: A Tragedy of Manners (Cambridge University Press, Cambridge, 2004).

Ross, R., and Schrikker, A., "The VOC Official Elite", in Worden, N. (ed.), Cape Town between East and West: Social Identities in a Dutch Colonial Town (Jacana, Johannesburg and Verloren, Hilversum, 2012), pp 26-44.

Russkiye diplomaticheskiye agenty $v$ Londone $v$ XVIII v. [Russian Diplomatic Agents in London in the 18th Century], Volume II (Warsaw, 1897).

Sbornik Imperatorskogo russkogo istoricheskogo obshtshestva [Almanac of the Imperial Russian Historical Society], Volume 114 (Yuryev, 1902).

Schutte, G.J., "Achter de Schermen: Hendrik Swellengrebel en de Kaapse Patriotten", Tydskrif vir Geesteswetenskappe, 59, 4 (2019), pp 562-586.

Schutte, G.J. (red.), Briefwisseling van Hendrik Swellengrebel Jr oor Kaapse sake 1778 1792 (Van Riebeeck-Vereniging, Kaapstad, 1982).

Schutte, G.J. (ed.), Hendrik Cloete, Groot Constantia and the VOC, 1778-1799, Documents from the Swellengrebel Archive (Van Riebeeck Society, Cape Town, 2003).

Schutte, G.J., (ed.), Hendrik Swellengrebel in Africa: Journals of Three Journeys in 17761777 (Van Riebeeck Society, Cape Town, 2018).

Schutte, G.J., Koloniaal Kaapstad in 1751-1752. Brieven van de Tantes Ten Damme aan hun Nichtjes Swellengrebel (Stichting Zuid-Afrikahuis Nederland, Amsterdam, 2020).

Schutte, G.J., De Nederlandse Patriotten en de koloniën. Een onderzoek naar hun denkbeelden en optreden 1770-1800 (Tjeenk Willink, Groningen, 1974).

Schutte, G.J. (ed.), Seer teder Beminde Heer Vader en Vrouw Moeder! Brieven van de Groninger Familie Fockens in de Oost, 1748-1783 (Verloren, Hilversum, 2014).

Senatskiy arkhiv [Senate Archives], Volume IV (July-September 1741) (Governing Senate, St Petersburg, 1891).

Staraya Moskva (Old Moscow), Volume 2 (Moscow, 1914).

Theal, G.M., History and Ethnography of Africa South of the Zambesi, Volume 2 (S Sonnenschein \& Co., London, 1909). 
Tieken, H., Between Colombo and the Cape: Letters in Tamil, Dutch and Sinhala Sent to Nicolaas Ondaatje from Ceylon, Exile at the Cape of Good Hope (1728-1737) (Manohar, Delhi, 2015).

Valentijn, F., Beschryvinge van de Kaap der Goede Hoope, Deel I (Van Riebeeck Society, Cape Town, 1971).

Veluwenkamp, J.W., Arkhangelsk. Niderlandskiye predprinimateli v Rossii. 1550-1785 [Archangelsk. Dutch Entrepreneurs in Russia. 1550-1785] (ROSSPEN, Moscow, 2006), p 178.

Ward, K., "Patrimonialism, Imperialism and Colonialism at the Cape of Good Hope under Dutch East India Company Rule, c. 1652-1795", in M.M. Charrad and J.P. Adams (eds), Patrimonial Capitalism and Empire (Emerald Group, Bingley, 2015), pp 91-113.

Wijnroks, E.H., Handel tussen Rusland en de Nederlanden, 1560-1640: Een Netwerkanalyse van de Antwerpse en Amsterdamse Kooplieden, Handelend op Rusland (Verloren, Hilversum, 2003).

Wilson, K., The Island Race: Englishness, Empire, and Gender in the Eighteenth Century (Routledge, London and New York, 2003).

Witsen, N., Moscovische reyse, 1664 - 1665: journaal en aentekeningen (Martinus Nijhoff, 's-Gravenhage, 1966).

Witsen, N., Puteshestviye v Moskoviyu 1664 - 1665. Dnevnik [Journey to Muscovy 1664 - 1665. A Diary] (Symposium, Saint Petersburg, 1996).

Worden, N., "Introduction", in Worden, N (ed.), Cape Town between East and West: Social Identities in a Dutch Colonial Town (Jacana, Johannesburg; Verloren, Hilversum, 2012), pp xi-xxii.

Zakharov, V.N., Zapadnoyevropeyskiye kuptsy v rossiyskoy torgovle XVIII veka [West European Merchants in the Russian Trade of the 18th Century] (Nauka, Moscow, 2005). 